\title{
Evaluating the Distance University Education Experience after Using the Zoom Application in Jordan from the Students Point of View
}

\author{
Jehad Ali Almomani", Mo'en Salman Alnasraween, Nusibah Ali Almosa \\ Faculty of Education and Psychology, Amman Arab University, Jordan
}

Received August 2, 2020; Revised October 12, 2020; Accepted October 24, 2020

\begin{abstract}
Cite This Paper in the following Citation Styles
(a): [1] Jehad Ali Almomani, Mo'en Salman Alnasraween, Nusibah Ali Almosa, "Evaluating the Distance University Education Experience after Using the Zoom Application in Jordan from the Students Point of View, "Universal Journal of Educational Research, Vol. 8, No. 11B, pp. 6239 - 6247, 2020. DOI: 10.13189/ujer.2020.082262.
\end{abstract}

(b): Jehad Ali Almomani, Mo'en Salman Alnasraween, Nusibah Ali Almosa (2020). Evaluating the Distance University Education Experience after Using the Zoom Application in Jordan from the Students Point of View. Universal Journal of Educational Research, 8(11B), 6239 - 6247. DOI: 10.13189/ujer.2020.082262.

Copyright $(2020$ by authors, all rights reserved. Authors agree that this article remains permanently open access under the terms of the Creative Commons Attribution License 4.0 International License

\begin{abstract}
This study aimed to evaluate the experience of distance university education using the zoom application from the viewpoint of Amman Arab University students. The study sample consisted of (326) male and female students. To achieve the aim of the study, the researchers prepared a measure to verify the degree of student satisfaction with the distance university education experience and its constraints from their viewpoint. After verifying its validity and reliability, the measure was applied to the study sample. The results showed that there was a moderate degree of satisfaction among students about the distance university education experience, and there were many obstacles faced by students during this experience; the most prominent of which were frequent internet outages during distance learning and students' failure to take notes. The finding also showed that there were statistically significant differences in the degree of satisfaction with the distance education experience attributable to the faculty and in favor of the human faculties, and the presence of statistically significant differences in the level of obstacles faced by students of human faculties during the distance education experience compared to scientific faculties, and the absence of relevant differences Statistical significance attributed to gender or academic program.
\end{abstract}

Keywords Distance University Education, Zoom Application, Distance Learning Obstacles

\section{Introduction}

The world witnessed a great development in technology and modern means of communication, which was reflected in the diversity of learning forms and methods. The uses of distance education have also increased significantly, as higher education institutions have become dependent on this pattern more in line with the technological and technical development in the world in all aspects of life, to meet the social and economic changes and requirements in society, which contributes to achieve the educational goals of the educational system and the development of society.

The technological revolution has led to the emergence of many styles and methods of teaching and learning, which necessitated the provision of a multi-source electronically rich environment that facilitated the learner the possibility of research and self-development. E-learning has become the main engine for all sciences and keeping pace with its developments. To achieve this, it was necessary to have proper planning and good preparation for computerized programs, applications and educational materials, in order to improve the educational outcomes of students and to enable the teachers to achieve all educational outcomes [5].

Distance education is one of the practical applications on e-learning that aims to liberate education from restrictions, and calls for the principle of equal opportunities and 
expansion in education, and the provision of education to the individual regardless of age. This type of education is concerned with the use of technical resources to make the learning process more flexible from the boundaries of space, time, content, testing and attendance. Thus, the opportunity of education is provided for people, who cannot access the traditional education system because of the economic, geographical, social or vocational situation. The success of this type of education depends on the readiness of university, the readiness of faculty members, the extent to which they have the necessary competencies to implement distance education, the readiness of learners themselves and their possession of the necessary competencies that enable them to deal with technology [12] Also, the availability of the state's infrastructure with the necessary equipment in cooperation with various telecommunications companies to operate at full operational capacity, especially in emergency conditions such as the Corona pandemic (COVID-19) that the world is exposed to this period is an important factor for the success of the distance learning experience in order to be the best and alternative option for regular education on campus.

With reference to the literature review and according to what the researchers pointed out, we find that there is no comprehensive definition of distance education. Among the definitions of distance education is the definition of Sadeghi [15] since he defined it as "an educational system based on the delivery of educational material to the learner through various technical means, so that the learner is far and separated from the teacher, and the union of the physical place is not required during the learning process."

The definition of UNESCO [16] as distance education focuses on open access to education and the provision of training, freeing learners from the constraints of time and space, and providing flexible learning opportunities for individuals and groups of learners using two-way communication.

It should be noted that distance education with all its advantages does not negate the presence of such obstacles facing the teacher and the learner alike, among these obstacles are the lack of expertise and competencies in the field of e-learning management, the inability to provide rapid maintenance of the devices in some remote places, the difficulty of accepting the change of the idea of traditional education and moving to distance e-learning, the Poor availability of the necessary financial capabilities and infrastructure to start work in e-learning, and the large number of students in the classroom reduces the teacher's ability to communicate with all students, and this is reflected negatively on educational outcomes [13,14].

There are other challenges facing education, such as financial and administrative challenges, professional challenges, and challenges related to the management, design and evaluation of e-learning. Also, the weakness of social awareness about distance education is a factor that contributes to impeding implementation, as some faculty members are reluctant to adopt this type of education and their desire to continue in traditional education, because dealing with the distance education system requires them effort, planning and good preparation in advance [2].

\section{Study Questions and Research Problems}

The Corona Virus pandemic has cast a shadow over the public and higher education sectors; all educational institutions were forced to close their doors to limit the chances of the virus spreading, and this decision raised great concern among workers and students about their work, study and future if this closure continues for a long time.

It is possible that the decision to activate distance education and rely on it in teaching with educational institutions worldwide can be taken to ensure the continuity of the educational process. But with the existence of simultaneous global conditions, the demand for distance education has increased for all students in universities and schools and that required good preparation by the university and provided the necessary capabilities for the successful implementation of distance education for all students without the occurrence of technical problems or external obstacles, and this is what required the necessity of not relying on Learning Management Systems only as part of its educational system, but rather to search for various electronic educational applications or platforms, such as: (ZOOM, MICROSOFT TEEMS) to implement the learning process and assess students.

This has created a major challenge for students and the faculty in dealing with distance education technology as the only option to complete the educational process. This study came to stand on the experience of distance education through the application (zoom cloud meeting) that was adopted at Amman Arab University, and to reveal the degree of satisfaction of university students with this experience and the obstacles they faced during that experience.

This study aimed to answer three research questions:

What is the degree of student satisfaction with the distance education university experience using the zoom application?

What are the obstacles that students faced during the distance education university experience using the Zoom application from their point of view?

Are there statistically significant differences in the degree of student satisfaction with the distance education university experience, and the obstacles that they encountered attributable to the variables of (college, program, and gender)?

\section{Research Significance}

The importance of this study is represented in that it revealed the experience of university education remotely, the degree of student satisfaction with it, and the challenges 
they faced during its implementation. Thus, it provides feedback to decision makers in universities in general and Amman Arab University in particular to reveal the strengths and weaknesses of the distance education experience and the obstacles to its implementation from the students' point of view, especially in light of its application in emergency circumstances, and this leads to improving the quality of services provided to students through the education platform, and reduce obstacles to using it to achieve a high degree of satisfaction with this type of education by the targeted.

\section{Study Terms and Definitions}

University distance education: It is the educational process that is implemented simultaneously from a distance using the Zoom application while communicating with university students to deliver educational content to them in different geographical locations in an interactive way using multiple educational media.

Distance education obstacles: These are all problems and difficulties that a university student faces during his ther learning through the distance education system, and these barriers are determined by the degree of student response in the field of distance education barriers that include a measure of distance learning experience prepared by researchers.

\section{Limitations of the Study}

This study was limited to Amman Arab University students in the bachelor's and master's degrees for the second semester of the academic year (2019/2020), and the results of this study were determined by the reliability and validity of the study tool that was prepared to achieve this study and the sample that will be applied to it.

\section{Literature Review}

Bray, Aoki, \& Dlugosh [7] conducted a study aimed at revealing the opinions of students enrolled in a distance-university degree program at a Japanese university accredited this program. The study sample consisted of (424) male and female students. To achieve the goal of the study, the researchers conducted a questionnaire to explore students' satisfaction with distance learning and their preferences. The results showed that students were generally satisfied with their distance learning and learning satisfaction was higher for students who could persevere in facing the challenges of distance learning, followed by students who found computers easy to use, then students who found it easy to interact with teachers, and in the last rank came students who did not prefer social interaction with others when learning.

Awad and Hills [3] conducted a study aimed at identifying the trend of graduate students in Palestinian universities towards distance learning technology. The sample of the study consisted of (91) male and female students studying postgraduate studies in the colleges of education in the Palestinian universities. To achieve its goals, a measure developed towards distance learning technology. The results showed that the attitudes of graduate students in Palestinian universities towards distance learning technology were positive. The results also showed that there were statistically significant differences in the responses of graduate students towards distance learning technology attributed to the university variable and in favor of the Islamic University. Moreover, the results showed that there were no statistically significant differences in their responses attributed to gender, educational level, and general assessment at the level of the tool as a whole.

Kuo, Walker, Belland \& Schroder [10] conducted a study aimed at predicting student satisfaction about online learning at Western University. The study sample consisted of (291) male and female students; they were all undergraduate and graduate students in the College of Education at Western University. To achieve the goal of the study, an online survey is conducted for these students. The results showed that there was a good degree of satisfaction for students, and the strongest indicator was the index of the learner's interaction with the learning content, and this confirms the importance of interaction in online learning, while interactions between students and self-organized learning did not contribute to achieving student satisfaction. The results also showed a significant impact of gender and the level of the class on the interaction of the learner - the learner, and the effect of the time spent each week on the Internet was largely influencing the Internet self-efficacy and self-regulation.

There are other studies that aimed to reveal the obstacles of distance learning among university students, including the study of Hamid [8], which aimed to know the problems that hinder the process of distance education in Sudanese universities. The study followed the descriptive approach. The study sample consisted of (1000) students chosen from Sudanese universities. To collect data, the researcher used a questionnaire. The results showed that the most problems that hinder the course of distance education in Sudanese universities were the ones related to the academic decisions, followed by the problems related to the administrative and financial laws and regulations of the Sudanese universities, then the problems related to admission and registration procedures, followed by the problems related to activating multimedia, while the problems related to the local community view and directions came in the last rank.

BaniYassin and Melhem [4] conducted as study aimed to reveal the obstacles facing the use of e-learning faced by school teachers for the first district of Irbid, and the impact of both gender, educational qualification and practical experience on that. The sample of the study consisted of 
(186) male and female teachers. After analyzing the results of the study, they indicated that all the items of the questionnaire formed obstacles to e-learning, and that there were statistically significant differences in the obstacles of e-learning attributed to the gender variable and in favor of males, and this indicates the ability of females to practice distance education more than males. The results also showed that there were no statistically significant differences attributable to the variables of the educational qualification and the number of years of experience.

Based on the foregoing, the results of the following studies Awad and Hilles [3]; Kuo.Y, et al [10]; Bray, Aoki, $\&$ Dlugosh [7] showed that there were positive attitudes and a good level of satisfaction with the distance learning experience of foreign and Arab university students. While the results of the study of Berry, Aoki and Dlugosh [7] showed that there were challenges facing the distance learning experience in universities, most notably the nature of the courses, followed by problems related to laws and administrative regulations. This study comes uniquely to reveal the degree of satisfaction of graduate students at Amman Arab University in Jordan about the experience of distance teaching, which has become mandatory in light of the Corona pandemic (COVID-19), for the purposes of improving and developing the process of distance teaching at this university and come up with recommendations related to this experience that can be circulated to other universities.

\section{Research Methodology}

This study used the analytical descriptive approach because of its suitability for the purposes of study.

\section{Study Population}

The study population consisted of all students of Amman Arab University who were enrolled in master's and bachelor's programs in all colleges at the Amman Arab University and they were (2130) male and female students for the academic year (2019/2020).

\section{Sample of The Study}

The study sample consisted of (326) male and female students with (15\%) from the graduate student community in Amman Arab University, and the sample was chosen in an accessible way, and a Google Drive link of the electronic scale was sent to the university faculty members to send it to their students. Table (1) shows the distribution of the sample population according to the college and gender variable:
Table 1. The distribution of the sample population

\begin{tabular}{|c|c|c|}
\hline The variable & Humanity & Scientific \\
\hline the college & 200 & 126 \\
\hline Total & Male & Female \\
\hline The variable & 129 & 197 \\
\hline Gender & \multicolumn{2}{|c|}{326} \\
\hline Total & Postgraduate & Bachelor \\
\hline The variable & 225 & 101 \\
\hline \multirow{2}{*}{ the program } & \multicolumn{2}{|c|}{326} \\
\cline { 2 - 3 } &
\end{tabular}

\section{Study Tools}

To achieve the objectives of this study, the scale of distance university education experience was developed.

The scale of distance university education experience

This scale was developed by referring to theoretical literature and previous studies, such as Allen, Bourhis, \& Mabry[1] and Beketova, Leontyeva, Ubanova [6]. The scaled reached (40) items, and the scale consisted of two fields: (Satisfaction with distance education and obstacles of distance education.) The researchers used a quintet Likert scale to answer it.

\section{Verifying the Validity of the scale}

To verify the validity of the scale content, the scale was presented to a group of nine referee with expertise in the Arabic language, measurement and evaluation, curricula and methods of teaching science. To ensure the items' validity and clarity, the referees' opinions and suggestions were collected and some of the items were amended. The scale in its final form yielded (33) items.

\section{Indicators of the Validity of structure}

To verify the validity of structure, they were verified by finding the parameters of the items correlation with the total score, and the results showed that the values of correlation coefficients were higher than (0.30), which indicates that the test has the validity of a suitable structure.

\section{Verifying the Reliability of the scale:}

To verify the consistency of scale, two ways were used. The first one was stabilization by repetition; through applying the study tool to a survey sample consisting of (25) male and female students from outside the main study sample. After two weeks have passed, the application has re-applied to the sample members themselves and the correlation coefficient between the two applications calculated. The second way was the internal consistency by the Cronbach alpha method. Table (2) shows these values. 
Table 2. The values of reliability coefficients using the test-retest method and the internal consistency by the Cronbach alpha method

\begin{tabular}{|c|c|c|}
\hline Features & $\begin{array}{c}\text { Stability (repeat } \\
\text { method) }\end{array}$ & $\begin{array}{c}\text { Cronbach } \\
\text { Alpha }\end{array}$ \\
\hline $\begin{array}{c}\text { Satisfaction with distance } \\
\text { education }\end{array}$ & $\mathbf{0 . 8 2}$ & $\mathbf{0 . 7 9}$ \\
\hline $\begin{array}{c}\text { Distance education } \\
\text { obstacles }\end{array}$ & $\mathbf{0 . 7 7}$ & $\mathbf{0 . 8 0}$ \\
\hline
\end{tabular}

Table (2) shows that the value of the reliability and internal consistency factors were all suitable for the purposes of the current study.

\section{Results and Discussion}

The results of answering and discussing the first study question, which states: What is the degree of student satisfaction with the experience of university education after using the Zoom application?

Arithmetic averages and standard deviations were extracted to the degree of student satisfaction with the distance university education experience as shown in Table (3).

Table 3. The Arithmetic averages and standard deviations for the degree of student satisfaction with the distance education university experience are in the descending order

\begin{tabular}{|c|c|c|c|c|c|}
\hline Number & Item & Mean & $\begin{array}{l}\text { Standard } \\
\text { deviation }\end{array}$ & Rank & Degree \\
\hline 1 & I can easily access the educational material & 3.79 & 1.24 & 1 & High \\
\hline 12 & Distance learning saves time and effort & 3.76 & 1.31 & 2 & High \\
\hline 19 & I can easily communicate with my teacher & 3.76 & 1.26 & 3 & High \\
\hline 17 & I feel easily integrated lecture & 3.69 & 1.20 & 4 & High \\
\hline 20 & $\begin{array}{l}\text { I can send and receive educational materials without } \\
\text { hindrance }\end{array}$ & 3.66 & 1.33 & 5 & Moderate \\
\hline 22 & $\begin{array}{l}\text { Distance education accompanies and employs electronic } \\
\text { programs and applications while implementing content. }\end{array}$ & 3.60 & 1.24 & 6 & Moderate \\
\hline 4 & $\begin{array}{l}\text { Sufficient information has been provided for the use of the } \\
\text { educational material website }\end{array}$ & 3.58 & 1.30 & 7 & Moderate \\
\hline 18 & $\begin{array}{l}\text { The teacher provides us with a registration of the } \\
\text { educational material }\end{array}$ & 3.57 & 1.32 & 8 & Moderate \\
\hline 10 & There are exercises and assignments that help me learn & 3.53 & 1.28 & 9 & Moderate \\
\hline 6 & $\begin{array}{l}\text { Distance education helps the learners to develop } \\
\text { themselves }\end{array}$ & 3.50 & 1.34 & 10 & Moderate \\
\hline 2 & $\begin{array}{l}\text { Distance learning gives me the courage to participate in the } \\
\text { lecture }\end{array}$ & 3.44 & 1.32 & 11 & Moderate \\
\hline 15 & $\begin{array}{l}\text { Distance learning gives me the courage to participate in the } \\
\text { lecture }\end{array}$ & 3.44 & 1.25 & 12 & Moderate \\
\hline 25 & Distance education has improved my thinking skills & 3.44 & 1.22 & 13 & Moderate \\
\hline 23 & I can attend the lecture without interruption & 3.40 & 1.28 & 14 & Moderate \\
\hline 5 & Evaluation takes place in different ways & 3.39 & 1.24 & 15 & Moderate \\
\hline 14 & Distance learning enables me to interact with the lecturer & 3.36 & 1.24 & 16 & Moderate \\
\hline 24 & $\begin{array}{l}\text { My evaluation is done continuously during the education } \\
\text { process }\end{array}$ & 3.35 & 1.29 & 17 & Moderate \\
\hline 7 & $\begin{array}{l}\text { There are those who help me in the case of any problems } \\
\text { concerning entering the distance learning }\end{array}$ & 3.34 & 1.31 & 18 & Moderate \\
\hline 16 & The used assessment methods are appropriate & 3.34 & 1.40 & 19 & Moderate \\
\hline 3 & The available electronically material is sufficient & 3.27 & 1.39 & 20 & Moderate \\
\hline 8 & I feel comfortable with the distance learning experience & 3.23 & 1.35 & 21 & Moderate \\
\hline 26 & The displayed content is interesting and not boring & 3.22 & 1.39 & 22 & Moderate \\
\hline 13 & $\begin{array}{l}\text { Distance learning helps me to understand the educational } \\
\text { material }\end{array}$ & 3.13 & 1.35 & 23 & Moderate \\
\hline 11 & Distance learning takes into account individual differences & 3.01 & 1.31 & 24 & Moderate \\
\hline 21 & I can focus more on distance learning than class lecture & 2.90 & 1.43 & 25 & Moderate \\
\hline 9 & E-learning is not different from education in the classroom & 2.58 & 1.50 & 26 & Moderate \\
\hline & Total degree & 3.24 & \multicolumn{2}{|c|}{1.04} & Moderate \\
\hline
\end{tabular}


It is noted from the results of Table (3) that the degree of satisfaction of Amman Arab University students with distance education in general was medium, with an arithmetic average of (3.24) and a standard deviation of (1.04); item (1) ranked first which states "I can Easily access the educational material " with an arithmetic average of (3.79) and with a standard deviation of (1.24), followed by items 12 and 19 that they stated " distance learning saves time and effort ", " I can easily communicate with my teacher " with an equal arithmetic average of (3.76), while item (9) came at the last rank, which stated that "e-learning is not different from education in the classroom" with an arithmetic average of (2.58) and a standard deviation (1.50) and with a moderate degree. The researchers attribute this result to the effectiveness of distance education, especially in the case that there are emergency conditions in communicating the educational content of students and enabling them to obtain this content at any time compared to the traditional education that depends on the presence of learners in the classroom. Moreover, distance education saves both the time and effort of the faculty members the students to display the content electronically at any time and places. This result is consistent with the results of the study of Awad and Hilles [3]; Kuo.Y, et al [10]; Bray \& et al [7] whose results showed the extent of students' satisfaction with the distance education university experience and its importance in achieving interaction between the parties of the educational process during Learning.

The results of answering and discussing the second study question, which states: What are the obstacles that students faced during the distance education university experience using the Zoom application from their point of view?

To answer this question, arithmetic averages and standard deviations were extracted for students' responses to the field of distance university education as shown in table (4).

It is noted from the results of Table (4) that the obstacles of distance university education which students faced during their learning came in general with a moderate degree, where the total arithmetic average of the obstacles reached (3.41) and with a standard deviation of (0.98). The obstacle mentioned in item (28) came first, which stated that "there is often an interruption with the Internet" with an arithmetic average of (3.94) and with a high degree, followed by item (32) in the second rank which states "I cannot take any notes during the class time" with an arithmetic average of (3.72) and with a high degree. Whereas, item (34) came to the last rank, which stated, "I do not think that the remote tests assess my achievement well "with an arithmetic average of (2.97) and with a moderate degree. The researchers attribute these results to the fact that the distance education experience is a new experience in our universities that has been resorted to and relied on completely without prior preparation by all universities, including the Arab Amman University, to face the emergency conditions that coincided with the spread of the pandemic Corona in the world, which led to a huge pressure on the telecommunications sector, which resulted in many technical problems related to the provision of the service and its quality in many regions. In addition to that, they attributed them to the Poor efficiency and readiness of faculty and students to implement distance education. This result is in line with the results of previous studies such as the studies of Hamid [8]; BaniYassin and Melhem[4] that indicated that there are several obstacles facing distance education in universities and schools, since teachers and students need to be prepared in advance to implement distance learning and education effectively.

Table 4. Arithmetic Averages and Standard Deviations of Student Responses to the Field of Obstacles to Distance Education Experience in Descending Order

\begin{tabular}{|c|c|c|c|c|c|}
\hline Number & Item & Mean & $\begin{array}{l}\text { Standard } \\
\text { deviation }\end{array}$ & Rank & Degree \\
\hline 28 & Internet outages often occur & 3.94 & 1.18 & 1 & High \\
\hline 32 & I cannot take any notes during the classroom time & 3.72 & 1.14 & 2 & High \\
\hline 33 & The lecturer cannot answer all students 'questions & 3.65 & 1.27 & 3 & Moderate \\
\hline 31 & The teacher starts the lecture late & 3.58 & 1.23 & 4 & Moderate \\
\hline 30 & $\begin{array}{l}\text { I don't feel that I have an educational atmosphere during } \\
\text { distance learning }\end{array}$ & 3.48 & 1.34 & 5 & Moderate \\
\hline 27 & $\begin{array}{l}\text { I hardly follow up distance learning lectures because of } \\
\text { the confusion around me }\end{array}$ & 3.41 & 1.37 & 6 & Moderate \\
\hline 29 & I trouble hearing the voice of the lecturer & 3.24 & 1.31 & 7 & Moderate \\
\hline 35 & $\begin{array}{l}\text { I cannot make better use of my time with distance } \\
\text { learning }\end{array}$ & 3.24 & 1.46 & 8 & Moderate \\
\hline 34 & $\begin{array}{l}\text { I do not think that the remote tests assess my } \\
\text { achievement well }\end{array}$ & 2.97 & 1.30 & 9 & Moderate \\
\hline & Total degree & 3.41 & \multicolumn{2}{|c|}{0.98} & Moderate \\
\hline
\end{tabular}


The results of answering the third study question, which states: Are there statistically significant differences in the degree of student satisfaction with the distance university education experience, and the obstacles that they encountered during it are attributed to the variables of (College, Program and Gender)?

To answer this question, arithmetic averages and standard deviations were calculated for the degree of satisfaction with distance learning and the obstacles that students faced according to the college, program and gender. Tables $(5,6,7)$ show that

Table 5. Arithmetic Averages and Standard Deviations for the Degree of Satisfaction with Distance Learning and Obstacles according to the College

\begin{tabular}{|c|c|c|c|}
\hline \multicolumn{2}{|c|}{ Dependent variable } & Mean & $\begin{array}{c}\text { Standard } \\
\text { deviation }\end{array}$ \\
\hline \multirow{2}{*}{$\begin{array}{c}\text { Satisfaction with } \\
\text { distance learning }\end{array}$} & Humanity & $\mathbf{3 . 4 8}$ & $\mathbf{0 . 9 8}$ \\
\cline { 2 - 4 } & Scientific & $\mathbf{2 . 9 9}$ & $\mathbf{0 . 8 6}$ \\
\hline \multirow{2}{*}{$\begin{array}{c}\text { The Obstacles of } \\
\text { distance learning }\end{array}$} & Humanity & $\mathbf{3 . 4 9}$ & $\mathbf{0 . 8 3}$ \\
\cline { 2 - 4 } & Scientific & $\mathbf{3 . 3 3}$ & $\mathbf{0 . 9 6}$ \\
\hline
\end{tabular}

Table 6. Arithmetic Averages and standard deviations for the degree of satisfaction with distance learning and obstacles according to the program

\begin{tabular}{|c|c|c|c|}
\hline Field & Program & Mean & Standard deviation \\
\hline \multirow{2}{*}{$\begin{array}{c}\text { Satisfaction with } \\
\text { distance learning }\end{array}$} & Bachelor & $\mathbf{3 . 4 0}$ & $\mathbf{0 . 8 7}$ \\
\cline { 2 - 4 } & Master & $\mathbf{3 . 0 7}$ & $\mathbf{0 . 9 8}$ \\
\hline $\begin{array}{l}\text { The Obstacles of } \\
\text { distance learning }\end{array}$ & Bachelor & $\mathbf{3 . 4 7}$ & $\mathbf{0 . 7 9}$ \\
\cline { 2 - 4 } & Master & $\mathbf{3 . 4 1}$ & $\mathbf{0 . 8 8}$ \\
\hline
\end{tabular}

Table 7. Arithmetic Averages and Standard Deviations for the Degree of Satisfaction with Distance Learning and Obstacles according to gender

\begin{tabular}{|c|c|c|c|}
\hline Field & Gender & Mean & Standard deviation \\
\hline \multirow{2}{*}{$\begin{array}{c}\text { Satisfaction with } \\
\text { distance learning }\end{array}$} & Male & $\mathbf{3 . 2 9}$ & $\mathbf{0 . 7 8}$ \\
\cline { 2 - 4 } & Female & $\mathbf{3 . 1 8}$ & $\mathbf{0 . 8 0}$ \\
\hline \multirow{2}{*}{$\begin{array}{c}\text { The Obstacles of } \\
\text { distance learning }\end{array}$} & Male & $\mathbf{3 . 4 6}$ & $\mathbf{0 . 9 8}$ \\
\cline { 2 - 4 } & Female & $\mathbf{3 . 4 1}$ & $\mathbf{0 . 7 9}$ \\
\hline
\end{tabular}

The results of the tables $(5,6,7)$ show that there are apparent differences between the arithmetic averages at the total degree according to each of the program, (Bachelor, Master), the college (human, scientific) and gender (male, female). To find out whether these differences are statistically significant, multiple variance analysis was extracted and Table (8) shows that.

Table 8. Results of the multiple variance analysis to examine the significance of the differences between the arithmetic averages for the degree of satisfaction of Amman Arab University students with distance education experience

\begin{tabular}{|c|c|c|c|c|c|c|}
\hline \multicolumn{2}{|c|}{ Source of variation } & Sum of squares & $\begin{array}{l}\text { Degree of } \\
\text { freedom }\end{array}$ & $\begin{array}{l}\text { Squares } \\
\text { Average }\end{array}$ & $\mathrm{f}$ & Significance level \\
\hline \multirow{3}{*}{ Gender } & $\begin{array}{c}\text { Satisfaction with } \\
\text { distance } \\
\text { education }\end{array}$ & .927 & 1 & .927 & 1.038 & .309 \\
\hline & $\begin{array}{l}\text { Obstacles of } \\
\text { distance } \\
\text { education }\end{array}$ & 1.100 & 1 & 1.100 & 2.171 & .142 \\
\hline & Total degree & .970 & 1 & .970 & 1.340 & .248 \\
\hline \multirow{2}{*}{ The college } & $\begin{array}{c}\text { Satisfaction with } \\
\text { distance } \\
\text { education }\end{array}$ & 15.897 & 2 & 7.949 & 8.900 & .000 \\
\hline & $\begin{array}{l}\text { Obstacles of } \\
\text { distance } \\
\text { education }\end{array}$ & 4.861 & 2 & 2.430 & 4.797 & .009 \\
\hline \multirow[b]{2}{*}{ The program } & Total degree & .212 & 1 & .212 & .237 & .626 \\
\hline & $\begin{array}{c}\text { Satisfaction with } \\
\text { distance } \\
\text { education }\end{array}$ & .010 & 1 & .010 & .019 & .890 \\
\hline \multirow[t]{2}{*}{ Error } & $\begin{array}{l}\text { Obstacles of } \\
\text { distance } \\
\text { education }\end{array}$ & 286.697 & 321 & .893 & & \\
\hline & Total degree & 162.618 & 321 & .507 & & \\
\hline \multirow{2}{*}{ Total } & $\begin{array}{c}\text { Satisfaction with } \\
\text { distance } \\
\text { education }\end{array}$ & 4077.231 & 326 & & & \\
\hline & $\begin{array}{l}\text { Obstacles of } \\
\text { distance } \\
\text { education }\end{array}$ & 4046.432 & 326 & & & \\
\hline
\end{tabular}


The results of Table (8) show that there are no differences attributed to gender and the academic program on the total degree and fields, while the results show that there are statistically significant differences attributed to the college at the total degree and the fields in favor of the human colleges. The researchers attribute this result to the nature of learning and the specificity of the courses in human colleges, which do not require laboratories or practical application compared to the scientific colleges, and therefore their satisfaction with this experience was higher. At the same time, the difficulties that they faced were more than other colleges, especially the obstacles arising from the difficulty of dealing with software and computers or accessing the web, due to the nature of their human specialties that do not need to deal with computers. In addition to that, the weakness of these students in dealing with technology compared to students of the scientific colleges. These results were consistent with what was indicated by BaniYassin and Melhem study [4], which showed that there were no statistically significant differences attributed to gender or experience in using e-learning as well as the results of the Awad and Hilles study[3], which revealed that there were no statistically significant differences in dealing with distance learning technology attributed to gender, educational qualification and experience.

\section{Recommendations}

In light of the results of the study, the researchers recommend the following:

- Encouraging the faculty members in universities and training them to implement distance education in teaching their courses, and urging them to spread the culture of distance learning among students.

- Raising the readiness of local communication companies and expanding the scope of internet service to all regions with the highest quality.

- Conducting more studies on the effectiveness of distance education compared to traditional education on other variables.

\section{REFERENCES}

[1] Allen, M., Bourhis, J. Burrell, N. \& Mabry, E. Comparing student satisfaction with distance education to traditional classrooms in higher education: A meta-analysis. The American Journal of Distance Education, VOL. 16, NO. 2, pp.83-97, 2002, doi.org/10.1207/S15389286AJDE1602_3.

[2] Al-Qudah, Khaled, and Al-Muqabilah, Bassam. E-learning challenges facing faculty members in private Jordanian universities. Al-Manara. Vol .19, No. 3, pp. 213-254. 2013.

[3] Awad, Munir Saeed, Hilles, \& Musa Saqr. The trend towards distance learning technology and its relationship to some variables among graduate students in Palestinian universities. Al-Aqsa University Journal (Humanities Series), VOL.19, NO.1, pp.219-256, 2015

[4] Bani Yassin, Bassam Mahmoud, and Melhem, Muhammad Amin. Barriers to using e-learning facing teachers in the Directorate of Education for the First District of Irbid, Palestinian Journal of Open Distance Learning, Ramallah, Palestine. VOL.3, NO. 5, pp. 115-136, 2011.

[5] Basak, K., Wotto, m., and Be'langer. E-learning, M-learning and D-learning: Conceptual definition and comparative analysis, E-Learning and Digital Media, VOL.15, NO.4, pp.191-216, 2018.doi.org/10.1177/204275 3018785180

[6] Beketova, E., Leontyeva, I., Zubanova, S. Creating an optimal environment for distance learning in higher education: discovering leadership issues. Palgrave Commun VOL. 6, NO. 66, pp. 123-155, 2020.doi.org/10.1 057/s41599-020-0456-x.

[7] Bray, E., Aoki, K., \& Dlugosh, L. Predictors of learning satisfaction in Japanese online distance learners. The International Review of Research in Open and Distributed Learning, VOL.9, NO. 3, 2008.doi.org/10.19173/irrodl.v9i 3.525 .

[8] Hamed, Sabah Al-Haj Muhammad. The problems that hinder the course of distance education in Sudanese universities: a field study from the view point of students of distance education in the centers of Sudanese universities for the academic year 2015-2016, Journal of Educational Sciences, Sudan University of Science and Technology. VOL.20, NO. 1, pp.47-33, 2019.

[9] Isik, A. H., Karakis, R. \&Guler, I. Postgraduate students' attitudes toward distance learning (the case study of Gazi University), Social and Behavioural Science, NO. 9, pp.218 - 222, 2010.doi.org/10.1016/j.sbspro.2010.12.139.

[10] Kuo, Y. C., Walker, A. E., Belland, B. R., \& Schroder, K. E. A predictive study of student satisfaction in online education programs. The International Review of Research in Open and Distributed Learning, VOL.14, NO. 1, pp.16-39, 2013.doi.org/10.19173/irrodl.v14i1.1338.

[11] Liu, Hong-Cheng Effects of Distance Learning on Learning Effectiveness, Eurasia Journal of Mathematics, Science \& Technology Education, VOL. 10, NO.6, 575-580, 2014.doi.org/10.12973/eurasia.2014.1218a.

[12] Mahruf, M. \& Shohel, C. Open and Distance Learning for Teachers' Professional Development: The English in Action (EIA) Model for the Global South, Book Section 5, (on line) Available: http://oro.open.ac.uk/id/eprint/32188, 2012.

[13] Oleksandrivna, Kharkiv; Andriivna, Koval; Ukraine, Koval. Distance Learning and Quarantine in the COVID-19 Pandemic Period. MODERN SCIENCE: PROBLEMS AND INNOVATIONS II International Scientific and Practical Conference Stockholm, Sweden 3-5 May, 2020.

[14] Pant, Ashish (2004). Distance Learning: History, Problems and Solutions, Advances in Computer Science and Information Technology (ACSIT). VOL. 1, NO. 2; November, pp.65-70, 2014.

[15] Sadeghi, Manijeh. A Shift from Classroom to Distance 
Learning: Advantages and Limitations. International Journal of Research in English Education, VOL 4, NO.1, pp.80-88, 2019.

[16] UNESCO. Open and distance learning-Trends, policy and strategy considerations, Paris, FR: UNESCO, 2002.

[17] Yin, M. C., Li, C. The theories and literature of distance education. Bulletin of Elementary Education, NO.10, pp.21-80, 201. 